\title{
INTERNET GOVERNANCE: TRENDS AND REALITIES. PART 1
}

\author{
Peter MAJOR \\ Vice-Chairman, United Nations Commission on Science \\ and Technology for Development (CSTD) \\ Address: Palais des Nations, 8-14, Av. de la Paix, 1211 Geneva 10, Switzerland \\ E-mail:pmajor@bluewin.ch
}

\begin{abstract}
Internet Governance is one of the global governance issues that emerged at the end of the 1990s. As the Internet is taking on an important role in every aspect of our lives, it has been recognized that its governance needs to involve all stakeholders and institutions to allow global access, foster development and contribute to the global economy, education, information. Security and privacy concerns should also be addressed in the policy dialogues. This paper outlines the global nature of the Internet Governance. It argues that in addition to dialogues and negotiations formal approaches should be explored to handle global issues in a global way. In its conclusion a mechanism is proposed to address Internet related global public policy issues.
\end{abstract}

The views expressed in this paper are solely those of the author in his private capacity and do not in any way represent the views of the UN Commission on Science and Technology for Development.

Key words: Internet, Internet Governance, global governance.

Citation: Major P. (2015) Internet Governance: Trends and realities. Part 1. Business Informatics, no. 4 (34), pp. 7-14. DOI: $10.17323 / 1998-0663.2015 .4 .7 .14$.

\section{Introduction}

$\mathrm{M}$ ore than 3 billion people, $42 \%$ of the world's population had access to the Internet as of the second quarter of 2014 [1]. This is a $741 \%$ growth from 2000 to 2014 . The Internet has evolved from an academic/military project to a global public utility [2].

The phenomenal evolution of the Internet raises many questions about its governance. Since the World Summit on the Information Society (WSIS) organized by the UN in December 2003 in Geneva and December 2005 in Tunis (http://www.itu.int/wsis/), many initiatives and proposals from governments, the technical community, academia, business, civil society and international organizations have tried to grasp the complexity of Internet Governance. The Geneva Plan of Action and Tunis Agenda documents reflected our understanding and assessment of the global public policy issues related to the Internet. At the end of 2015, the UN General Assembly will review the implementation of the Action Lines for- mulated in the Geneva Plan of Action and will decide on the way forward. It is useful to assess the achievements from a different angle.

In this paper, I analyze the global nature of Internet Governance, its common characteristics with other global governance systems, as well as its specific features. After dealing with governance, global issues and global governance approaches in general, I describe the characteristics of Internet Governance, the similarities we can find with other governance systems and the impact of the growth and global penetration of the Internet on IG.

There are many open questions: how can we extend off-line arrangements to the on-line space? are traditional national governance mechanisms adaptable to the Internet? and can we apply formal approaches to Internet Governance?

At the end of the paper, I briefly discuss the lessons learned and what is the way forward Internet Governance. 


\section{Governance, global issues, global governance}

In traditional governance, a governing or political authority and institutions ultimately exercise control; formal political institutions aim at coordinating and controlling interdependent social relations that also possess the capacity to enforce decisions. Informal governance works more toward practices and guidelines. In the process of governance, collective interests are articulated, rights and obligations are established and differences are mediated.

A possible definition of governance is offered by Thomas G. Weiss and Ramesh Thakur: «All processes of governing, undertaken by a government, market or network, over a family, tribe, organization or territory through formal laws, norms, power or language or informal guidelines or practices» [3].

Issues such as climate change, nuclear arms proliferation, use of outer space or radio communication, to name a few, have trans-border or global impact. Handling these issues requires global approaches and ultimately global governance.

Global governance may be characterized as the «sum of laws, norms, policies, and institutions that define, constitute, and mediate trans-border relations between states, cultures, citizens, intergovernmental and nongovernmental organizations, and the market. Global governance is the regulation of interdependent relations in the absence of overarching political authority, such as in the international system» [4].

Approaches to handling global issues reflect an appreciation of the problems and are influenced by the political environment. Up to the 1990s, global issues were mostly negotiated in a multilateral setting i.e.: in the country delegations only representatives of governments and some technical advisors participated in the discussions. Based on the results of negotiations, decisions were taken by the governments.

An early and successful example of global governance is the global regulatory framework of radio communication known as Radio Regulations (RR) [5]. The RR is an international treaty of the International Telecommunication Union (ITU), a specialized agency of the United Nations. The RR was created to avoid harmful interference. The first edition of the treaty dates from 1906. The text of the RR, considering rapid technological progress, needs to be modified regularly by the World Radiocommunication Conferences (WRC) organized by the ITU. In the preparatory phase and in the work of the Conference, stakeholders from the technical community, business and academia participate as advisors within the respective national delegations. The signatories of the treaty are representatives of Member States.

More recent examples of multilateral global governance are the Outer Space Treaty (Treaty on Principles Governing the Activities of States in the Exploration and Use of Outer Space, including the Moon and Other Celestial Bodies, 1967 [6]) and the International Treaty on the Non-proliferation of Nuclear Arms, 1968 [7].

Global governance is an ongoing process with successes and failures. Some of the failures may be attributed to governance gaps. There are five main governance gaps: knowledge gaps, normative gaps, policy gaps, institutional gaps and compliance gaps [4].

\section{Knowledge gaps}

There is often little or no consensus about the nature, causes, gravity, and magnitude of a problem, as well as about the empirical information or the theoretical explanation. There is often disagreement over the best remedies and solutions to these problems (examples: climate change, nuclear energy). The academic and technical community, such as universities, research institutes, scientific experts and think tanks, as well as civil society actors (NGOs) currently are playing a growing role in filling the gap.

\section{Normative gaps}

The norm is statistically a pattern of behavior that is most common or usual (normal curve), whereas an ethical norm is a pattern of behavior that should be followed in accordance with a given value system or the moral code of a society, a generally accepted standard of proper behavior. The two meanings may converge in practice; in most cases, they will complement each other; but in some cases, they may diverge. The $\mathrm{UN}$ is an arena where member states codify norms either as soft law (UN resolutions, declarations) or hard law (international conventions and treaties) seeking consensus about normative approaches to address global challenges. In practice, however, because of dissent by powerful states or mischief by large coalitions of less powerful ones, either no action occurs, or agreement is possible only on a lowestcommon denominator.

\section{Policy gaps}

Policy is an interlinked set of governing principles and goals, and the agreed programs of action to implement those principles and achieve those goals. It is important 
to understand that even if the source and scale of most of today's pressing challenges are global, and any effective solution to them must also be global, the policy authority for tackling these challenges remains vested in states. UN policy implementation is not by the Secretariat but by member states.

\section{Institutional gaps}

Institutions are formal organizations, but they may also be informal entities. If the policy is to escape the trap of being ad hoc, episodic, judgmental and idiosyncratic, it must be housed within an institution with resources and autonomy. Institutional gaps may exist for different reasons: absence of institutions, missing stakeholders or inadequate resources. It is up to the governments who are the driving force to fill the gap.

\section{Compliance gaps}

Agreed elements of international policy may not be complied with for lack of ability, resources or will of implementation. There is no clear mandate of any UN institution to have the monitoring authority, responsibility and capacity. Non-compliance may be defined as the lack of strength of conviction or commonality of interests to enforce the community norm. In the UN system, there is only a limited possibility and capacity to ensure that states comply with agreed international policy.

\section{Global governance: multilateral approach}

Interrelations of global issues have been explored in a systematic and scientific way ever since the second half of the last century. One of the most influential publications was «The Limits to Growth», commissioned by the Club of Rome in 1972 [8]. «The Limits to Growth» appeared at a time when human belief in the power of technology was at an all time high. There seemed to be no challenge that could not be overcome through application of human ingenuity and effort, in the form of economic growth based on continuing technological advance.

In this perspective, «The Limits to Growth» warned that the 2010-30 period would see some resources becoming scarce or expensive (for example regional scarcity of oil, water, fish, wood, land) while environmental damage would become increasingly visible (for example regional destruction of biodiversity, accumulation of toxics, ozone-destroying chemicals, and greenhouse gases). And importantly, all of this would occur in spite of continuing technological advance. «The limits to Growth» emphasized that resource and pollution problems would occur because the world is physically finite - and actually quite small compared to the human footprint in the 21st century. The problems would start regionally, and gradually embrace the world - unless corrective action was taken immediately. Man was no longer omnipotent (https://ic.fsc.org/).

In response to global problems judged to be urgent, two more UN lead initiatives may be mentioned: the Montreal Protocol to protect the ozone layer (1989) [9] and the Kyoto Protocol, the UN Framework Convention on Climate Change (1992) [10].

The importance of global issues was fully recognized at the beginning of 1990s. The UN held its first Conference on Environment and Sustainable Development in Rio de Janeiro in 1992 and adopted an agenda for the environment and development in the 21st century. Agenda 21: A Programme of Action for Sustainable Development contains the Rio Declaration on Environment and Development, which recognizes each nation's right to pursue social and economic progress and assigned to States the responsibility for adopting a model of sustainable development. Agreements were also reached on the Convention on Biological Diversity and the Framework Convention on Climate Change [11]. This Rio conference was followed by the UN Conference on Population in 1994 in Cairo and subsequently by the UN Conference on Women in 1995, Beijing.

In 2000, the leaders of the world made a historic commitment: to eradicate extreme poverty and improve the health and welfare of the world's poorest people within 15 years. The commitment, adopted at the Millennium Summit in September 2000, was set forth in the United Nations Millennium Declaration [12]. This vision was expressed in eight time-bound goals, known as the Millennium Development Goals (MDGs):

$\downarrow$ to eradicate extreme poverty and hunger;

$\downarrow$ to achieve universal primary education;

$\downarrow$ to promote gender equality and empower women;

$\downarrow$ to reduce child mortality;

$\downarrow$ to improve maternal health;

$\checkmark$ to combat HIV/AIDS, malaria, and other diseases;

$\checkmark$ to ensure environmental sustainability;

$\checkmark$ to develop a global partnership for development.

High level review of the implementation of the Millennium Development Goals (2000 - 2015) and discussion on post-2015 goals (known as Sustainable Development Goals) held in September 2015, in the UN, New York. 


\section{Global governance: multi-stakeholder approach}

In parallel with the full recognition of the importance of global issues, it has also been recognized that global issues should be addressed with the involvement of all stakeholders i.e.: with the representatives of governments, business, civil society, the technical and academic community and the international/intergovernmental organizations participating in the discussions and the decision-making. This approach is known as the multistakeholder approach.

The functions of multi-stakeholder initiatives are to identify global public needs, facilitate negotiation, gather and disseminate knowledge, create and correct markets, broaden participation in global governance.

The framework of multi-stakeholder initiatives needs international organizations, stakeholders need to be included early. The approach should be embedded in national policy debates. Transparency is instrumental and the approach should lead to accountability.

There are many challenges to multi-stakeholder initiatives: in addition to the known constraints of the multilateral approach influenced by divergent political interests of governments. Stakeholders from business have particular interests. Civil society has no clear legitimate representation and it is difficult to create mutual trust among different stakeholders considering that in the multi-stakeholder global governance model representatives of stakeholders participate in the discussions on an equal footing in their respective roles.

There are several examples of multi-stakeholder initiatives:

$\diamond$ The World Commission on Dams (WCD) formed in April 1997 to research the environmental, social and economic impacts of the development of large dams globally (http://www.unep.org/DAMS/WCD/). Members: civil society, academia, the private sector, professional associations and one government representative. Act in an individual capacity, not representing the organizations or governments of which they are members.

$\diamond$ The Forest Stewardship Council (FSC) is an international non-for-profit, multi-stakeholder organization established in 1993 to promote responsible management of the world's forests. Its main tools for achieving this are a standard setting, certification and labeling of forest products. The organization aims to «provide businesses and consumers with a ... tool to influence how forests worldwide are managed» (https:// ic. fsc.org/).
Global Fund to Fight Aids, Tuberculosis and Malaria Public-private partnership Programs are supported by the Global Fund in more than 140 countries. As of mid-2014, they had 6.6 million people on antiretroviral therapy for AIDS. They have tested and treated 11.9 million people for TB, and have distributed 410 million insecticide-treated nets to protect families against malaria (http://www.theglobalfund. org/en/).

\section{Global Internet Governance}

Similarly to other global issues, the relevance of ICTs and the global nature of the Internet were also recognized at the end of 1990 s, leading to the WSIS. The notion of Internet Governance emerged after the first phase of the WSIS. The Declaration of Principles document adopted by the Geneva Summit [13] asked the Secretary General of the UN to establish a Working Group on Internet Governance «to investigate and make proposals for action, as appropriate, on the governance of the Internet by 2005». The task of this Working Group, established in 2004, was to organize an open dialogue on Internet Governance (WGIG) among all stakeholders and to bring recommendations on this subject to the second phase of the Summit.

The WGIG in its report proposed the following working definition of Internet governance: «Internet governance is the development and application by Governments, the private sector and civil society, in their respective roles, of shared principles, norms, rules, decision-making procedures, and programmes that shape the evolution and use of the Internet» [14]

The WGIG identified the following public policy clusters:

(a) Issues relating to infrastructure and the management of critical Internet resources, including administration of the domain name system and Internet protocol addresses (IP addresses), administration of the root server system, technical standards, peering and interconnection, telecommunications infrastructure, including innovative and convergent technologies, as well as multilingualization. These issues are matters of direct relevance to Internet governance and fall within the ambit of existing organizations with responsibility for these matters;

(b) Issues relating to the use of the Internet, including spam, network security and cybercrime. While these issues are directly related to Internet governance, the nature of global cooperation required is not well defined; 
(c) Issues relevant to the Internet have an impact much wider than the Internet and for which existing organizations are responsible, such as intellectual property rights (IPRs) or international trade. The WGIG started examining the extent to which these matters are being handled consistently with the Declaration of Principles;

(d) Issues relating to the developmental aspects of Internet governance, in particular capacity-building in developing countries.

During the second phase of WSIS held in Tunis in December 2005, the WGIG report served as the basis to create the Internet Governance Forum (IGF). As for the role of governments in Internet Governance to handle public policy issues, the magic formula of «enhanced cooperation» was introduced and discussions on implementation of enhanced cooperation are ongoing.

It is important to mention here some of the most significant organizations in the Internet Governance space.

The Internet Corporation for Assigned Names and Numbers (ICANN) (https://www.icann.org/) is a nonprofit association (based in US since 1998). Its main mission is the management of identifiers (common pool resource). It is considered as a Global Multi-Stakeholder Agency with the following functions:

a. Notary (IANA functions and assignment of protocol parameters);

b. Competition Authority;

c. Regulator of the «Semantic Spectrum» (TLD space).

ICANN also develops and enforces policies (via contracts). Its governing body is an elected international Board (direct and ICANN Nominating Committee).

The Internet Society (ISOC), including the Internet Engineering Task Force (IETF) and the Internet Architecture Board (IAB), facilitates open development of standards, protocols, administration, and the technical infrastructure of the Internet. It supports education in developing countries specifically, and wherever the need exists it promotes professional development and builds a community to foster participation and leadership in areas important to the evolution of the Internet. It provides reliable information about the Internet.

The UN, ITU, UNESCO, UNCTAD, UNDP, UNEP, FAO, WIPO, WHO, WMO and other UN specialized agencies are facilitators for the WSIS Action Lines. The Commission on Science and Technology for Development (UN CSTD) is responsible for reviewing the activities of the facilitators for the WSIS Action Lines. There are several initiatives and forums, in addition to the formal organizations where different aspects of internet governance are discussed NetMundial (http://www.netmundial.br/), Carl Bildt Initiative (https://www.cigionline.org/activity/globalcommission-internet-governance), etc.

One of the proposals formulated in the WGIG report was to remove US government oversight of ICANN. This process started in March 2014 with the announcement of the US Government asking for proposals about the transition of its stewardship to a multi-stakeholder arrangement with a target date of 30 September 2015 (https://www.icann.org/stewardship).

Another proposal of the WGIG report was to create under the UN a discussion forum on Internet-related public policy issues with non-binding results. In 2006, the UN, following the outcomes of the WSIS, created a secretariat for the organization of the Internet Governance Forum (IGF). The first IGF was held in 2006 in Athens. The event concentrated on openness, critical Internet resources, security, diversity, emerging issues and the way forward. The IGF has become an annual event with an increasing number of participants during its 10 years of history. The IGF is a multi-stakeholder dialogue involving governments, civil society, academia and technical community, business and international organizations. It is not a decision making body, there are no formal negotiations and no binding documents are produced. It brings together stakeholders in an informal setting and creates a framework for cooperation. It also contributes to development and capacity building. Attendance of the IGFs varies from around 1000 (2006, Athens) to more than 3000 (2014, Istanbul). It is the task of the Multi-stakeholder Advisory Group nominated by the Secretary General of the UN to shape the IGF program, determining the overarching theme and the sub-themes, and to evaluate the workshop submissions. On average, there are more than 100 workshops under the sub-themes and several presentations organized by the dynamic coalitions (relatively informal, issue-specific groups consisting of stakeholders that are interested in the particular issue). In addition to workshops and dynamic coalition meetings, there are several activities taking place in the IGF meeting: best practices forums, open forums, flash sessions, inter-regional dialogue sessions, pre-events, and the IGF Village.

The main challenge of Internet Governance is to enable coexistence in shared cross-border digital spaces 
The overarching themes and the main sessions of the IGFs

Table 1.

\begin{tabular}{|c|c|c|c|}
\hline Year & Venue & Overarching theme & Sub-themes \\
\hline 2006 & $\begin{array}{l}\text { Athens } \\
\text { (Greece) }\end{array}$ & $\begin{array}{l}\text { Internet Governance } \\
\text { for Development }\end{array}$ & $\begin{array}{l}\text { - Security • Diversity } \quad \text { • Access } \\
\text { - The Way Forward } \quad \text { Emerging Issues }\end{array}$ \\
\hline 2007 & $\begin{array}{l}\text { Rio de Janeiro } \\
\text { (Brazil) }\end{array}$ & $\begin{array}{l}\text { Internet Governance } \\
\text { for Development }\end{array}$ & $\begin{array}{l}\text { - Critical Internet Resources • Access • Diversity } \\
\text { - Security • Taking Stock and the Way Forward } \\
\text { - Emerging Issues }\end{array}$ \\
\hline 2008 & $\begin{array}{l}\text { Hyderabad } \\
\text { (India) }\end{array}$ & Internet for All & $\begin{array}{l}\text { - Reaching the Next Billion, Promoting Cyber-Security and Trust } \\
\text { - Managing Critical Internet Resources } \\
\text { - Emerging Issues - the Internet of Tomorrow } \\
\text { - Taking Stock and the Way Forward }\end{array}$ \\
\hline 2009 & $\begin{array}{l}\text { Sharm el Sheikh } \\
\text { (Egypt) }\end{array}$ & $\begin{array}{l}\text { Internet Governance - } \\
\text { Creating Opportunities for All }\end{array}$ & $\begin{array}{l}\text { - Critical Internet Resources } \bullet \text { Security, Openness and Privacy } \\
- \text { Diversity } • \text { Access } \bullet \text { IG in the Light of WSIS Principles } \\
\text { - Taking Stock } \quad \text { E Emerging Issues - Impact of Social Networks }\end{array}$ \\
\hline 2010 & $\begin{array}{c}\text { Vilnius } \\
\text { (Lithuania) }\end{array}$ & $\begin{array}{l}\text { IGF } 2010 \text { - Developing } \\
\text { The Future Together }\end{array}$ & $\begin{array}{l}\text { - Managing Critical Internet Resources } \\
\text { - Security, Openness and Privacy Access and Diversity } \\
\text { - Internet Governance for Development } \\
\text { - Emerging Issues: Cloud Computing Taking stock of Internet Governance } \\
\text { and the Way Forward }\end{array}$ \\
\hline 2011 & $\begin{array}{l}\text { Nairobi } \\
\text { (Kenya) }\end{array}$ & $\begin{array}{l}\text { Internet as a Catalyst for Change: } \\
\text { Access, Development, Freedoms } \\
\text { and Innovation }\end{array}$ & $\begin{array}{l}\text { - Internet Governance for Development } \\
\text { - Emerging Issues } \\
\text { - Managing Critical Internet Resources } \\
\text { - Security, Openness and Privacy } \\
\text { - Access and Diversity } \\
\text { - Taking Stock and the Way Forward }\end{array}$ \\
\hline 2012 & $\begin{array}{c}\text { Baku } \\
\text { (Azerbaijan) }\end{array}$ & $\begin{array}{c}\text { Internet Governance } \\
\text { for Sustainable Human, Economic } \\
\text { and Social Development }\end{array}$ & $\begin{array}{l}\text { - Emerging Issues } \\
\text { - Managing Critical Internet Resources } \\
\text { - Internet Governance for Development } \\
\text { - Access and Diversity } \\
\text { - Security, Openness and Privacy } \\
\text { - Taking Stock and the Way Forward }\end{array}$ \\
\hline 2013 & $\begin{array}{c}\text { Bali } \\
\text { (Indonesia) }\end{array}$ & $\begin{array}{l}\text { Building Bridges - Enhancing } \\
\text { Multi-stakeholder Cooperation } \\
\text { for Growth and Sustainable } \\
\text { Development }\end{array}$ & $\begin{array}{l}\text { - Building Bridges - The Role of Governments in Multistakeholder } \\
\text { Cooperation } \\
\text { - Internet Governance Principles } \\
\text { - Principles of Multistakeholder Cooperation } \\
\text { - Legal and other Frameworks: Spam, Hacking and Cybercrime } \\
\text { - (Access/Diversity): The Internet as an Engine For Growth } \\
\text { and Sustainable Development } \\
\text { - Human Rights, Freedom of Expression and Free Flow } \\
\text { of Information on the Internet } \\
\text { - Emerging Issues - Internet Surveillance } \\
\text { - Open Microphone }\end{array}$ \\
\hline 2014 & $\begin{array}{l}\text { Istanbul } \\
\text { (Turkey) }\end{array}$ & $\begin{array}{l}\text { Connecting Continents } \\
\text { for Enhanced Multistakeholder } \\
\text { Internet Governance }\end{array}$ & $\begin{array}{l}\text { - Policies Enabling Access } \\
\text { - Content Creation, Dissemination and Use Internet } \\
\text { as an Engine For Growth \& Development } \\
\text { - IGF \& The Future of the Internet Ecosystem } \\
\text { - Enhancing Digital Trust } \\
\text { - Internet and Human Rights } \\
\text { - Critical Internet Resources } \\
\text { - Emerging Issues }\end{array}$ \\
\hline 2015 & $\begin{array}{l}\text { João Pessoa } \\
\text { (Brazil) }\end{array}$ & $\begin{array}{c}\text { Evolution of Internet Governance: } \\
\text { Empowering Sustainable } \\
\text { Development }\end{array}$ & $\begin{array}{l}\text { - Cybersecurity and Trust } \quad \text { Internet Economy } \\
\text { - Inclusiveness and Diversity } \quad \text { Openness } \\
\text { - Enhancing Multistakeholder Cooperation } \\
\text { - Internet and Human Rights } \quad \text { - Critical Internet Resources } \\
\text { - Emerging Issues }\end{array}$ \\
\hline
\end{tabular}


of billions of people with very diverse personal values and legal frameworks (http://www.euro-ssig.eu/). Recently the distinction has been proposed between governance of the Internet and governance on the Internet. In this approach, governance of the Internet covers the public policy cluster (a) identified by the WGIG and is formalized in the Internet protocol suite. Standards and protocols of the suite have been developed in a multi-stakeholder approach based on so-called rough consensus. Governance on the Internet covers public policy clusters (b), (c) and (d). The global nature of the Internet requires harmonization of legal systems, understanding of different political interests, acceptance of cultural differences, applying already existing legal frameworks to the Internet, etc. This leads to the need for identifying existing mechanisms dealing with global public policy issues related to the governance on the Internet and identifying gaps in the absence of these mechanisms.
The UN General Assembly in its resolution created the CSTD Working Group on Enhanced Cooperation (WGEC) with the mandate to «examine the mandate of WSIS regarding Enhanced Cooperation through seeking, compiling and reviewing inputs from all Member States and all other stakeholders, and to make recommendations on how to fully implement this mandate» [15]. The CSTD WGEC identified public policy issues and started a mapping exercise to identify existing mechanisms and gaps. The results of the exercise have been summarized in the conference room paper prepared by the CSTD Secretariat [16].

Discussions on the results of implementation of the Geneva Plan of Action and the Tunis Agenda have been conducted in UNESCO in Paris in 2013 followed by the High Level Meeting in the ITU in Geneva in 2014. The final high level review meeting of the WSIS will be held in December 2015 during the General Assembly of the United Nations in New York.

\section{References}

1. Internet World Stats (2014) Internet users in the world. Available at: http://www.internetworldstats.com/stats.htm (accessed 31 January 2015).

2. Leiner B.M., Cerf V., Clark D.D., Kahn R.E., Kleinrock L., Lynch D.C., Postel J., Roberts L.G., Wolff S. (2015) A brief history of the Internet. Internet Society. Available at: http://www.internetsociety.org/internet/what-internet/historyinternet/brief-history-internet (accessed 24 February 2015).

3. Weiss T.G. (2013) Global governance: Why? What? Whither? Cambridge (UK): Polity Press.

4. Weiss T.G. (2009) The UN's role in Global Governance. UN Intellectual History Project, Briefing Note Number 15. Available at: http://www.unhistory.org/briefing/15GlobalGov.pdf (accessed 31 January 2015).

5. International Telecommunication Union (2012) Radio regulations. Geneva: ITU. Available at: http://www.itu.int/dms pub/itu-s/oth/02/02/S02020000244501PDFE.pdf (accessed 31 January 2015).

6. United Nations Office for Outer Space Affairs (1967) Treaty on principles governing the activities of states in the exploration and use of outer space. Available at: http://www.unoosa.org/oosa/SpaceLaw/outerspt.html (accessed 31 January 2015).

7. United Nations Office for Disarmament Affairs (1968) Treaty on the non-proliferation of nuclear weapons (NPT). Available at: http://www.un.org/disarmament/WMD/Nuclear/NPT.shtml (accessed 31 January 2015).

8. Club of Rome Organization (2012) What was the message of «The limits to growth». Available at: http://www.clubofrome. org/flash/limits_to_growth.html (accessed 31 January 2015).

9. United Nations Environment Programme, Ozone Secretariat (1989) The Montreal protocol on substance that depletes the ozone layer. Available at: http://ozone.unep.org/new_site/en/montreal_protocol.php (accessed 31 January 2015).

10. United Nations Framework Convention on Climate Change (1992) Kyoto Protocol. Available at: http://unfccc.int/2860. php (accessed 31 January 2015).

11. United Nations Conference on Sustainable Development (2012) The history of sustainable development in the United Nations. Available at: http://www.uncsd2012.org/history.html (accessed 31 January 2015).

12. 12. United Nations (2000) United Nations Millennium Declaration. Available at: http://www.un.org/millennium/declaration/ares552e.htm (accessed 31 January 2015).

13. World Summit on the Information Society (2003) Document WSIS-03/GENEVA/DOC/4-E, 12 December 2003. Available at: http://www.itu.int/net/wsis/docs/geneva/official/dop.html (accessed 31 January 2015).

14. Working Group on Internet Governance (2005) Report of the Working Group on Internet Governance, Chateau de Bossey, June 2005. Available at: http://www.wgig.org/docs/WGIGREPORT.pdf (accessed 31 January 2015).

15. United Nations (2012) United Nations General Assembly Resolution A/Res/67/195. Available at: http://www.un.org/en/ $\mathrm{ga} / \mathrm{search} / \mathrm{view}$ doc.asp?symbol=A/RES/67/195 (accessed 31 January 2015).

16. United Nations CSTD Secretariat (2015) The mapping of international Internet public policy issues. Conference room paper. Geneva, Switzerland. 


\title{
УПРАВЛЕНИЕ ИНТЕРНЕТОМ: ТЕНДЕНЦИИ И РЕАЛЬНОСТЬ. ЧАСТЬ 1
}

\author{
П. МЕЙОР \\ заместитель руководителя Комиссии ООН по науке и технологиям \\ Adpec: Palais des Nations, 8-14, Av. de la Paix, 1211 Geneva 10, Switzerland \\ E-mail:pmajor@bluewin.ch
}

\begin{abstract}
Управление Интернетом представляет собой одно из направлений глобального управления, активно развиваюшееся с кониа 1990-х годов. Поскольку Интернет играет важную роль в нашей жизни, представляется необходимым вовлечение в процессы управления всех заинтересованных лии и институтов, $a$ также способствование развитию и вкладу вмировую экономику, образование и информационное обеспечение. Вопросы информационной безопасности и конфиденциальности также должсны рассматриваться в рамках обсуждения политики в области управления Интернетом. В данной статье рассматривается глобальный аспект управления Интернетом. Показано, что в дополнение к обсуждениям и переговорам должны применяться формальные подходы, позволяюшие решать глобальные вопросы. Предлагается подходк решению вопросов, связанных с глобальной политикой в области управления Интернетом.
\end{abstract}

Выводы и рекомендации, приведенные в статье, отражают исключительно личное мнение автора и не должны трактоваться в качестве официальной позиции Комиссии ООН по науке и технологиям.

Key words: Интернет, управление Интернетом, глобальное управление.

Цитирование: Major P. Internet Governance: Trends and realities. Part 1 // Business Informatics. 2015. No. 4 (34). P. 7-14. DOI: 10.17323/1998-0663.2015.4.7.14.

\section{Литература}

1. Internet users in the world (2014) // Internet World Stats [Электронный pecypc]: http://www.internetworldstats.com/stats.htm (дата обращения 31.01.2015)

2. A brief history of the Internet / B.M. Leiner [et al.] // Internet Society [Электронный pecypc]: http://www.internetsociety.org/internet/whatinternet/history-internet/brief-history-internet (дата обращения 24.02.2015).

3. Weiss T.G. Global governance: Why? What? Whither? Cambridge (UK): Polity Press, 2013. $180 \mathrm{pp}$.

4. Weiss T.G. The UN's role in Global Governance // UN Intellectual History Project, Briefing Note Number 15, 2009 [Электронный ресурс]: http://www.unhistory.org/briefing/15GlobalGov.pdf (дата обращения 31.01.2015).

5. Radio regulations. Geneva: International Telecommunication Union (ITU), 2012. [Электронный pecypc]: http://www.itu.int/dms_pub/itu-s/ oth/02/02/S02020000244501PDFE.pdf (дата обращения 31.01.2015).

6. Treaty on principles governing the activities of states in the exploration and use of outer space. United Nations Office for Outer Space Affairs, 1967 [Электронный pecypc]: http://www.unoosa.org/oosa/SpaceLaw/outerspt.html (дата обращения 31.01.2015).

7. Treaty on the non-proliferation of nuclear weapons (NPT). United Nations Office for Disarmament Affairs, 1968 [Электронный ресурс]: http:// www.un.org/disarmament/WMD/Nuclear/NPT.shtml (дата обрашения 31.01.2015).

8. What was the message of «The limits to growth». Club of Rome Organization, 2012 [Электронный pecypc]: http://www.clubofrome.org/flash/ limits_to_growth.html (дата обращения 31.01.2015).

9. The Montreal protocol on substance that depletes the ozone layer. United Nations Environment Programme, Ozone Secretariat, 1989 [Электронный pecypc]: http://ozone.unep.org/new_site/en/montreal_protocol.php (дата обращения 31.01.2015).

10. Kyoto Protocol. United Nations Framework Convention on Climate Change, 1992 [Электронный pecypc]: Available at: http://unfccc.int/2860. php (дата обращения 31.01.2015).

11. The history of sustainable development in the United Nations // United Nations Conference on Sustainable Development, 2012 [Электронный pecypc]: http://www.uncsd2012.org/history.html (дата обращения 31.01.2015).

12. United Nations Millennium Declaration. United Nations, 2000 [Электронный pecypc]: http://www.un.org/millennium/declaration/ares552e. htm (дата обращения 31.01.2015).

13. Document WSIS-03/GENEVA/DOC/4-E, 12 December 2003 // World Summit on the Information Society, 2003 [Электронный ресурс]: http://www.itu.int/net/wsis/docs/geneva/official/dop.html (дата обращения 31.01.2015).

14. Report of the Working Group on Internet Governance, Chateau de Bossey, June 2005 // Working Group on Internet Governance, 2005 [Электронный ресурc]: http://www.wgig.org/docs/WGIGREPORT.pdf (дата обращения 31.01.2015).

15. United Nations General Assembly Resolution A/Res/67/195. United Nations, 2012) [Электронный pecypc]: http://www.un.org/en/ga/search/ view_doc.asp?symbol=A/RES/67/195 (дата обращения 31.01.2015).

16. The mapping of international Internet public policy issues. Conference room paper. Geneva: United Nations CSTD Secretariat, 2015. 22 pp. 